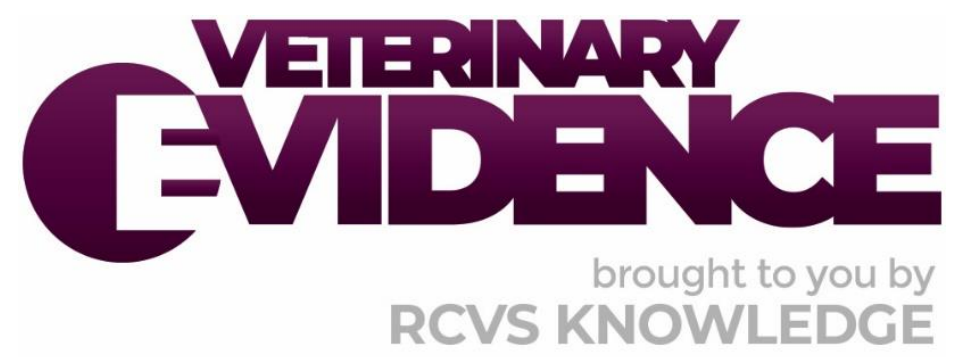

\title{
Insulin choice in feline diabetes mellitus
}

\author{
A Knowledge Summary by
}

Yaiza Gómez Mejías LdaVet MANZCVS (Medicine of Cats) ISFM Adv Cert Feline Behaviour MRCVS ${ }^{1^{*}}$

\footnotetext{
${ }^{1}$ La Gatera Medicina Felina, Lomo del Capón 74, 35017 Tafira Alta, Las Palmas de Gran Canaria, Canary Islands, Spain

*Corresponding Author (yaizagomezmejias@yahoo.co.uk)
}

ISSN: 2396-9776

Published: 06 Aug 2021

in: The Veterinary Evidence journal Vol 6, Issue 3

DOI: https://doi.org/10.18849/ve.v6i3.407

Reviewed by: Nicki Reed (BVM\&S CertVR DSAM (Feline)

DipECVIM-CA FRCVS) and Sam Taylor (BVetMed(Hons) CertSAM DipECVIM-CA FRCVS)

Next Review Date: 22 Feb 2023 


\section{KNOWLEDGE SUMMARY}

\section{PICO question}

In cats with diabetes mellitus, do protamine zinc insulin (PZI) and glargine show a similar effect in reducing clinical signs and hypoglycaemia episodes?

\section{Clinical bottom line}

\section{Category of research question}

Treatment

\section{The number and type of study designs reviewed}

The number and type of study designs that were critically appraised was one. This study was a nonrandomised retrospective trial. A systematic review was also found, which analyses the influence of insulin in diabetic remission

\section{Strength of evidence}

Weak

\section{Outcomes reported}

Compared to PZI, using glargine in recently diagnosed diabetic cats fed exclusively an ultra-low carbohydrate-high protein canned diet, may result in lower fructosamine and mean 12 hour blood glucose concentrations as well as less episodes of hypoglycaemia

\section{Conclusion}

In view of the strength of evidence and the outcomes from the study the following conclusion is made: in cats with diabetes mellitus where currently licensed insulin fails to result in a good glycaemic control, glargine may be considered

\section{How to apply this evidence in practice}

The application of evidence into practice should take into account multiple factors, not limited to: individual clinical expertise, patient's circumstances and owners' values, country, location or clinic where you work, the individual case in front of you, the availability of therapies and resources.

Knowledge Summaries are a resource to help reinforce or inform decision making. They do not override the responsibility or judgement of the practitioner to do what is best for the animal in their care.

\section{Clinical Scenario}

A recently diagnosed diabetic cat shows a poor glycaemic and clinical response to protamine zinc insulin (PZI). You wonder whether there is sufficient evidence of superiority of efficacy of glargine over PZI to justify use of this insulin for avoiding hypoglycaemia whilst controlling the clinical signs. 


\section{The evidence}

Only one peer-reviewed study was found where the effects of glargine were directly compared to those of PZI in diabetic cats. This study is a non-randomised trial and provides weak evidence about the superiority of glargine at reducing episodes of hypoglycaemia, lowering fructosamine levels and achieving higher rates of remission.

For completeness purposes the references were scrutinised and a relevant systematic review was found. This systematic review provides a strong level of evidence of the lack of existing evidence regarding a significant correlation between the type of insulin and diabetic remission. However, episodes of hypoglycaemia were not considered in this review.

\section{Summary of the evidence}

\section{Marshall et al. (2009)}

\begin{tabular}{|c|c|}
\hline Population: & $\begin{array}{l}\text { Cats presenting to a feline-only veterinary practice in Australia with } \\
\text { newly diagnosed diabetes without serious concurrent disease. }\end{array}$ \\
\hline Sample size: & 24 cats \\
\hline Intervention details: & $\begin{array}{l}\text { Diagnosis of diabetes mellitus was based on glucose } \\
\text { concentration, serum fructosamine and glycosuria. Presence } \\
\text { of clinical signs consistent with diabetes mellitus was used as } \\
\text { supporting evidence. } \\
\text { - The cats were split into three insulin treatment groups of } \\
\text { eight cats in each, at the time of first diagnosis based on } \\
\text { breed (Burmese or non-Burmese) and previous } \\
\text { corticosteroid administration. } \\
\text { - Cats were classified as having uncomplicated diabetes if they } \\
\text { were still eating or complicated diabetes mellitus if signs of } \\
\text { systemic illness (depression and anorexia) and dehydration } \\
\text { were observed. } \\
\text { Cats with uncomplicated diabetes were treated with their } \\
\text { allocated insulin type within } 12 \text { hours. Cats with complicated } \\
\text { diabetes were initially treated with fluid therapy and } \\
\text { intravenous regular insulin until appetite returned and } \\
\text { hydration status was normal. } \\
\text { - All cats were placed on a sole ultra-low carbohydrate-high } \\
\text { protein canned diet (Purina Diabetes Management) for } 16 \\
\text { weeks or until remission was achieved. Dietary caloric } \\
\text { restriction was recommended after the first } 2 \text { weeks of } \\
\text { treatment for cats with body condition score (BCS)> } 6 \text { (on a } \\
\text { scale } 1-9 \text { ). } \\
\text { Inclusion in the trial was confirmed at day } 10 \text {. Cats were } \\
\text { excluded up to day } 10 \text { if they did not eat the prescribed diet, } \\
\text { or owners were unable to exclusively feed the diet or } \\
\text { measure water intake. } \\
\text { Every group was treated with either: } \\
\quad \mathrm{n}=8 \text { porcine lente insulin } 40 \mathrm{U} / \mathrm{ml} \text { (Caninsulin }{ }^{\oplus} \text {; } \\
\quad \text { Intervet); } \\
\quad \mathrm{n}=8 \mathrm{PZI} 40 \mathrm{U} / \mathrm{ml} \text { (PZI-Vet, Idexx Pharmaceuticals } \\
\quad \text { USA }\end{array}$ \\
\hline
\end{tabular}




\begin{tabular}{|c|c|}
\hline & $\begin{array}{l}\text { or } \mathrm{n}=8 \text { glargine } 100 \mathrm{U} / \mathrm{ml} \text { (Lantus }{ }^{\circledR} \text {; Aventis } \\
\text { Pharmaceuticals) twice daily subcutaneously (SC). } \\
\text { - The initial dose of } 0.5 \mathrm{U} / \mathrm{kg} \text { ideal body weight was given if } \\
\text { the blood glucose concentration on admission was greater } \\
\text { than or equal to } 20 \mathrm{mmol} / \mathrm{l} \text {, and } 0.25 \mathrm{U} / \mathrm{kg} \text { if blood glucose } \\
\text { concentration was less than } 20 \mathrm{mmol} / \mathrm{l} \text {. } \\
\text { Blood glucose concentration was measured every } 2 \text { hours } \\
\text { for } 12 \text { hours for each cat for the first } 3 \text { days of treatment. } \\
\text { - After a minimum of } 2 \text { weeks, cats in remission were } \\
\text { discharged from hospital and had their blood glucose } \\
\text { concentration measured weekly for } 3 \text { months. } \\
\text { Hospital assessments were made after discharge to confirm } \\
\text { remission on days } 10,17 \text { and } 28 \text { and then every } 2 \text { weeks. } \\
\text { Assessments included serial measurements of blood glucose } \\
\text { (every } 2 \text { hours for } 12 \text { hours) and serum fructosamine } \\
\text { measurements (every } 4 \text { weeks). Insulin was adjusted } \\
\text { accordingly. } \\
\text { Trial end-point: } 16 \text { weeks of treatment or remission date. }\end{array}$ \\
\hline Study design: & Non-randomised trial \\
\hline Outcome studied: & $\begin{array}{l}\text { Glycaemic control and remission probabilities in cats treated with } \\
\text { either glargine, PZI or porcine lente insulin based on the mean } \\
\text { glucose concentration, mean daily water intake and serum } \\
\text { fructosamine using analysis or variance. }\end{array}$ \\
\hline $\begin{array}{l}\text { Main findings: } \\
\text { (relevant to PICO question): }\end{array}$ & $\begin{array}{l}\text { - Glargine was associated with lower mean } 12 \text { hour blood } \\
\text { glucose concentrations. } \\
\text { - } \quad \text { Fructosamine concentration was significantly lower in } \\
\text { glargine treated cats from day } 56 \text {. } \\
\text { - } \text { hone of the glargine treated cats exhibited signs of } \\
\text { hypoglycaemia despite many having biochemical } \\
\text { hypoglycaemia. } \\
\text { - Two cats treated with porcine lente insulin and one cat } \\
\text { treated with PZI had severe clinical hypoglycaemia. } \\
\text { - Daily water intake in glargine treated cats was not different } \\
\text { in the first } 28 \text { days of therapy. } \\
\text { - There was no difference in body weight based on type of } \\
\text { insulin used. } \\
\text { The probability of remission was greater in cats treated with } \\
\text { glargine than those treated with PZI or porcine lente insulin. } \\
\text { By week } 16 \text {, all cats in the glargine group had achieved } \\
\text { remission while only } 2 / 8 \text { cats in the porcine lente insulin } \\
\text { group and } 3 / 8 \text { cats in the PZI group had achieved it. } \\
\text { Cats with lower mean } 12 \text { hour blood glucose concentration } \\
\text { on day } 17 \text { had a higher probability of subsequent remission } \\
\text { than cats with higher mean glucose concentration. } \\
\text { - Probabilities of remission were similar and did not differ } \\
\text { significantly between Burmese and non-Burmese cats. }\end{array}$ \\
\hline Limitations: & $\begin{array}{l}\text { - Small group size } \\
\text { - Cats presented at a feline only practice may not be } \\
\text { representative of the average first opinion practice patient. } \\
\text { - Cats with complicated diabetes were excluded, which may }\end{array}$ \\
\hline
\end{tabular}




\begin{tabular}{|l|l|}
\hline make the sample less representative of the whole \\
population.
\end{tabular}

\begin{tabular}{|c|c|}
\hline & \\
\hline Population: & 111 reports assessed using eligibility criteria \\
\hline Sample size: & 22 studies were included \\
\hline Intervention details: & $\begin{array}{l}\text { Study identification and data collection following Cochrane } \\
\text { Collaboration guidelines: } \\
\text { - The search was carried out to answer two questions: } \\
\text { 1. What aspects of a cat's treatment might affect the } \\
\text { remission rate achieved? } \\
\text { 2. What diagnostic test results or characteristics might } \\
\text { predict remission in a diabetic cat? } \\
\text { - An online bibliographical search for literature relevant to the } \\
\text { two questions was performed on } 18 \text { December } 2012 \text { using } \\
\text { three different databases (PubMed, VetMed Resource and } \\
\text { CAB Abstracts). } \\
\text { Bias assessment and evidence grading: } \\
\text { - Risk of bias in each study was independently assessed by } \\
\text { each author using bias assessment forms. Disagreement } \\
\text { between authors was settled by subsequent discussion. } \\
\text { - A statement describing how persistent euglycaemia was } \\
\text { confirmed after anti-hyperglycaemic treatment had been } \\
\text { discontinued for a minimum of } 2 \text { weeks needed to be } \\
\text { included for the criteria for remission to be considered } \\
\text { adequate. A minimum follow-up of } 3 \text { months was judged } \\
\text { adequate for remission to occur. } \\
\text { - Periodontal disease, previous diabetic ketoacidosis, and } \\
\text { urinary tract infections for which antibiotic treatment was } \\
\text { administered were not classified as concurrent diseases } \\
\text { when describing the populations of included studies. } \\
\text { Inclusion criteria: } \\
\text { 1. published in English in a peer-reviewed journal; } \\
\text { 2. must address one, or both, of the above research questions; } \\
\text { 3. must contain original research (excluding review articles); } \\
\text { 4. must describe more than three cats (excluding individual } \\
\text { case reports and small case series). }\end{array}$ \\
\hline
\end{tabular}




\begin{tabular}{|c|c|}
\hline & $\begin{array}{l}22 \text { included studies were included in two categories: } \\
\text { 1. those assessing the effect of pharmaceutical intervention } \\
\text { and diet on remission rate; } \\
\text { 2. those assessing diagnostic tests and cat characteristic as } \\
\text { predictors of remission. }\end{array}$ \\
\hline Study design: & Systematic review \\
\hline Outcome studied: & $\begin{array}{l}\text { The strength of evidence regarding the following remission related } \\
\text { aspects were studied: } \\
\text { - Factors influencing remission rate pharmaceutical } \\
\text { intervention: Oral anti-hyperglycaemic agents, insulin } \\
\text { glargine, porcine lente insulin, PZI, insulin detemir, Neutral } \\
\text { Protamine Hagedorn, home glucose monitoring. } \\
\text { - Factors influencing remission rate: diet } \\
\text { - Predictors of remission: diagnostic tests, cat characteristics } \\
\text { and treatment regime }\end{array}$ \\
\hline $\begin{array}{l}\text { Main findings: } \\
\text { (relevant to PICO question): }\end{array}$ & $\begin{array}{l}\text { GLARGINE } \\
\text { - Glargine was the most commonly investigated insulin } \\
\text { The study published by Marshall et al. (2009) is the only trial } \\
\text { to directly compare remission rates achieved with different } \\
\text { twice-daily insulins. An evaluation of the level of evidence of } \\
\text { the pharmaceutical intervention revealed several } \\
\text { limitations: } \\
\text { Bias: } \\
\text { 1. The study population was potentially not } \\
\text { comparable to general population. } \\
\text { 2. A small sample reduced the power of the study. } \\
\text { 3. High risk of inclusion of acromegalic cats. } \\
\text { 4. Presence of possible confounding factors. } \\
\text { Confounding factors: } \\
\text { 1. The protocol for porcine lente insulin was } \\
\text { different from that of glargine and PZI, making } \\
\text { dosing protocol a potential confounding factor. } \\
\text { 2. There were differences between groups in the } \\
\text { number of cats with urinary tract infections. } \\
\text { 3. Since reversible forms of insulin resistance can } \\
\text { lead to a greater chance of remission, previous } \\
\text { corticosteroid treatment was considered a } \\
\text { confounding factor too. } \\
\text { Lack of blinding. } \\
\text { O Positive findings in studies with low statistical power } \\
\text { are at greater risk of being false-positives compared } \\
\text { to those in studies with high statistical power. } \\
\text { of glargine in diabetic remission was classified as 3a (1 being } \\
\text { the highest and 4d the lowest level of evidence in the } \\
\text { grading system used (Centre for Evidence-Based Medicine } \\
\text { (CEBM), 2011)). }\end{array}$ \\
\hline
\end{tabular}




\begin{tabular}{|c|c|}
\hline & $\begin{array}{l}\text { PZI - Marshall et al. (2009): same limitations mentioned above. } \\
\text { - One study documented no episodes of remission after } 45 \\
\text { days, but cats were most likely normoglycaemic by the end } \\
\text { point. } \\
\text { - A non-randomised trial designed to assess the effect of } \\
\text { dietary composition reported a remission rate of } 68 \% \text { in in } \\
\text { cats predominantly treated with twice-daily PZI and fed a } \\
\text { low-carbohydrate, low fibre diet. } \\
\text { - The evidence provided by the review regarding the influence } \\
\text { of use of PZI in diabetic remission was classified as } 3 b \text {. } \\
\text { Overall pharmaceutical intervention: weak evidence for correlation } \\
\text { between insulin type and remission. }\end{array}$ \\
\hline Limitations: & $\begin{array}{l}\text { - Questions cannot be clearly addressed because of difficulties } \\
\text { such as a general lack of consensus about the definition of } \\
\text { diabetic remission, its duration and characteristics. } \\
\text { - Some of the studies were designed for purposes different to } \\
\text { remission. } \\
\text { - The process of assessment is clearly described. However the } \\
\text { combination of different interventions (dietary and } \\
\text { pharmaceutical) could have interfered with the assessment } \\
\text { and conclusions. } \\
\text { - Hypoglycaemia or other complications of diabetic treatment } \\
\text { were not taken into account. }\end{array}$ \\
\hline
\end{tabular}

\section{Appraisal, application and reflection}

Long acting insulin (PZI, glargine or detemir) and high-protein/low-carbohydrate diets are recommended for the management of diabetic cats (Behrend et al. 2018; and Sparkes et al. 2015). Diabetes mellitus is a common disorder that affects a cat's quality of life and survival. An appropriate management is key to positively contribute to their welfare and the cat-human bond.

The UK veterinary prescription cascade precludes the use of human insulin (e.g.: glargine, detemir) as first line treatment. ProZinc ${ }^{\circledast}$ (Boehringer Ingelheim Vetmedica), a human PZI produced by recombinant DNA technology (PZIR), is the only long acting insulin licensed for use in cats in the UK. However, a large part of the literature about diabetic management and remission in cats involves glargine trials (Gostelow et al. 2014).

A shift regarding feline diabetic remission is taking place and seems to be considered a main goal by many experts (Marshall et al. 2009; and Gostelow et al. 2014). However, the tight glycaemic control (Nack \& DeClue, 2014) needed to achieve that period of time in which symptoms of diabetes are absent, is potentially concerning, as it may result in episodes of hypoglycaemia which may affect the cat's quality of life. Whereas in 2015 the ISFM guidelines (Sparkes et al., 2015) highlighted the convenience of 'avoiding hypoglycaemia at the expense of allowing periods of hyperglycaemia', in 2018 Behrend et al. stated that 'In cats, diabetic remission is a reasonable goal'.

However, limiting the cat's clinical signs, using a treatment that fits into the owner's daily life and preventing clinically significant hypoglycaemia and other complications are clear goals in both current guidelines of management of feline diabetes (Sparkes et al., 2015; and Behrend et al., 2018).

Most long-term effects on health, quality of life and cost effectiveness of a near-euglycaemic management and remission paradigm is unknown (Nack \& DeClue, 2014). On the other hand, more comorbidities are included in the diagnostic work up nowadays. Over the last few decades new feline pathologies influencing the onset and 
management of diabetes have been identified and technical instruments are more readily available making it possible to diagnose these diseases. A close monitoring of the glycaemic levels and the work up of these comorbidities result in additional expenses and difficulties to achieving stabilisation of the feline diabetic patient (Gostelow et al., 2014).

Hence, when cost and effectiveness are outweighed, remission may be considered a goal but most veterinarians priorities may still be reducing clinical signs and likelihood of hypoglycaemic episodes. To avoid controversy, 'remission' has not been included as a keyword in the search but remission related evidence was not excluded from the search results and was taken into account.

At the time of writing, the study of Marshall et al. (2009) is the only peer-reviewed publication where PZI and glargine are directly compared. The evidence provided by this non-randomised trial regarding the superiority of glargine compared to PZI at reducing clinical signs in diabetic cats is weak.

With respect to the clinical signs, daily water intake in glargine treated cats was not different in the first 28 days of therapy, despite being associated with lower mean 12 hour blood glucose concentrations than porcine lente insulin and PZI. An extended trial period would have been necessary to assess the medium to long-term effects, since fructosamine concentrations were reported to be significantly lower in glargine treated cats from day 56. There was no significant effect of insulin type on change in body weight from initial hospital discharge to trial end.

However, the trial provides stronger evidence about influence of insulin type on the development of hypoglycaemia. During the trial, two cats treated with porcine lente insulin and one cat treated with PZI had severe clinical signs associated with low blood glucose levels, whereas none of the glargine treated cats exhibited signs of hypoglycaemia.

To ensure the completeness of the Knowledge Summary, references of selected search results were scrutinised. A relevant systematic review about feline diabetic remission (Gostelow et al., 2014) was found amongst them and included in the search table after applying the exclusion criteria.

The systematic review does not fully answer the PICO question because hypoglycaemia or other complications of treatment were not taken into account.

It was included in the Knowledge Summary because it analyses the evidence in the study published by Marshall et al. (2009). However, one of three confounding factors described in the review was unrelated to this PICO question as it was linked to the porcine lente insulin dosing protocol, which is not a type of insulin included in this Knowledge Summary. With respect to the confounding factor associated with the use of steroids, as explained by Marshall et al. (2009), the glargine group was disadvantaged with respect to the probability of remission compared to the other groups and that disadvantage could compensate the bias.

Regarding the overall conclusion, the systematic review shows a slightly lower existing evidence for remission in cats treated with PZI (3b) compared to glargine (3a), 1 being the highest and $4 \mathrm{~d}$ the lowest grade of evidence (Table 1 in Gostelow et al., 2014).

Another potentially relevant study (Gostelow et al., 2017) was found during scrutinisation of the references. The results were included in the 2017 ACVIM Forum Research Abstract Forum, but were excluded from this summary as were other non-peer-reviewed publications since a detailed description of the study was not available and an assessment of possible biases could not be made.

A limitation of this Knowledge Summary could be the omission of the keyword 'remission'. However, a similar search including this keyword was made and the results were not significantly different and did not include the systematic review published by Gostelow et al. (2014) either. 
Another limitation could be that the PZI used in the trial published by Marshall et al. (2009) is a mixture of $90 \%$ beef and $10 \%$ pork insulin (PZI-Vet, Idexx ${ }^{\circledR}$ Pharmaceuticals USA, Westbrook, Maine USA) and not the PZIR (Boehringer Ingelheim). However, there is some evidence about similar results of PZI-Vet and PZIR (Nelson et al., 2009).

An observation made whilst reviewing these papers was a low level of satisfaction of owners with their veterinarian's knowledge of diabetes 'which may reflect owner access to the rapidly changing body of knowledge on the Internet' (Aptekmann et al., 2014). There is also a possible bias in the veterinary literature, where the importance of temporary remission seems overestimated compared to that of limitation of clinical signs and hypoglycaemia.

Complete studies with large samples are difficult to perform due to the lack of adequate cases and it is possible that investigating other treatments and formulations such as incretins and glargine $300 \mathrm{U} / \mathrm{mL}$ (Gilor et al., 2016; and Saini et al., 2020) may be more appealing to researchers now. Multiple factors affect the prognosis of diabetes in cats that deserve some attention too and may be understandably leading the way in research.

There is more literature about glargine than about any other insulin type in cats and its use has been demonstrated to be safe and effective. There is weak evidence about glargine helping to achieve lower fructosamine levels as well as possibly reducing the likelihood of hypoglycaemia when it is directly compared to PZI. However, the results are mainly based on newly diagnosed diabetes, what may not reflect the situation of the majority of the population.

\section{Methodology Section}

\begin{tabular}{|c|c|}
\hline \multicolumn{2}{|l|}{ Search Strategy } \\
\hline $\begin{array}{r}\text { Databases searched and dates } \\
\text { covered: }\end{array}$ & $\begin{array}{l}\text { CAB Abstracts on OVID Platform } 1973 \text { - Week } 07 \text { 2021] } \\
\text { VetMed } 1973 \text { - February } 2021 \\
\text { Pubmed } 1973 \text { - February } 2021\end{array}$ \\
\hline Search terms: & $\begin{array}{l}\text { CAB Abstracts and VetMed: } \\
\text { (cat OR cats OR feline OR felines OR queen OR tom) AND (diabetes } \\
\text { mellitus OR diab*)) and (PZI OR protamine zinc insulin OR human } \\
\text { recombinant protamine zinc insulin OR ProZinc) and (improvement } \\
\text { OR glycaemic control OR glycemic control OR hyperglycaemia OR } \\
\text { hyperglycemia OR hypoglycaemia OR hypoglycaemia OR blood } \\
\text { glucose OR weight OR body condition score OR clinical signs OR } \\
\text { polyuria OR polydipsia) } \\
\text { (cat OR cats OR feline OR felines OR queen OR tom) AND (diabetes } \\
\text { mellitus OR diab*)) and (PZI OR protamine zinc insulin OR human } \\
\text { recombinant protamine zinc insulin OR ProZinc) and (Glargine OR } \\
\text { Lantus OR iGlar) } \\
\text { PubMed: } \\
\text { (cat OR cats OR feline OR felines OR queen OR tom) AND (diabetes } \\
\text { mellitus OR diab*))(PZI OR protamine zinc insulin OR human } \\
\text { recombinant protamine zinc insulin OR ProZinc) AND (Glargine OR } \\
\text { Lantus OR iGlar) AND (improvement OR glycaemic control OR }\end{array}$ \\
\hline
\end{tabular}




\begin{tabular}{|c|c|}
\hline & $\begin{array}{l}\text { glycemic control OR hyperglycaemia OR hyperglycemia OR } \\
\text { hypoglycaemia OR hypoglycaemia OR blood glucose OR weight OR } \\
\text { body condition score OR clinical signs OR polyuria OR polydipsia) }\end{array}$ \\
\hline Dates searches performed: & 22 Feb 2021 \\
\hline \multicolumn{2}{|l|}{ Exclusion / Inclusion Criteria } \\
\hline Exclusion: & $\begin{array}{l}\text { - Excel was initially used to find duplicates. Duplicates that } \\
\text { this initial approach failed to find were removed along the } \\
\text { exclusion process. } \\
\text { - Studies that did not involve domestic cats were excluded. } \\
\text { Studies that only included either iGlar or PZI were not } \\
\text { included. } \\
\text { - Case reports, clinical reviews, guidelines, congress abstracts } \\
\text { only were excluded to achieve a certain level of scientific } \\
\text { evidence. } \\
\text { - Studies where the PICO question was not addressed were } \\
\text { excluded. }\end{array}$ \\
\hline Inclusion: & $\begin{array}{l}\text { - Studies that involved both PZI and iGlar in domestic cats } \\
\text { with diabetes mellitus were included. } \\
\text { A thorough scrutinisation of the references was made and } \\
\text { relevant studies offering a strong level of evidence were } \\
\text { included. }\end{array}$ \\
\hline
\end{tabular}

\begin{tabular}{|c|c|c|c|c|c|c|}
\hline \multicolumn{7}{|c|}{ Search Outcome } \\
\hline Database & $\begin{array}{l}\text { Number } \\
\text { of results }\end{array}$ & $\begin{array}{l}\text { Excluded - } \\
\text { Duplicates }\end{array}$ & $\begin{array}{l}\text { Excluded - } \\
\text { Non feline, } \\
\text { non PZI or } \\
\text { iGlar related }\end{array}$ & $\begin{array}{l}\text { Excluded - } \\
\text { Non-English, } \\
\text { case reports, } \\
\text { clinical reviews, } \\
\text { guidelines, } \\
\text { congress } \\
\text { abstracts }\end{array}$ & $\begin{array}{c}\text { Excluded - } \\
\text { Did not address } \\
\text { the PICO } \\
\text { question }\end{array}$ & $\begin{array}{c}\text { Total } \\
\text { relevant } \\
\text { papers }\end{array}$ \\
\hline $\begin{array}{l}\mathrm{CAB} \\
\text { Abstracts }\end{array}$ & 62 & 28 & 10 & 7 & 17 & 0 \\
\hline VetMed & 195 & 106 & 45 & 12 & 31 & 1 \\
\hline PubMed & 387 & 46 & 312 & 23 & 6 & 0 \\
\hline \multicolumn{6}{|c|}{ Total relevant papers when duplicates removed } & 1 \\
\hline
\end{tabular}


The author declares no conflicts of interest.

I would like to thank Clare Boulton for her help during the search process.

\section{REFERENCES}

1. Aptekmann, K. P., Armstrong, J., Coradini, M. \& Rand, J. (2014). Owner Experiences in Treating Dogs and Cats Diagnosed with Diabetes Mellitus in the United States. Journal of the American Animal Hospital Association. 50(4), 247-253. DOI: https://doi.org/10.5326/JAAHA-MS-6101

2. Behrend, E., Holford, A., Lathan, P., Rucinsky, R. \& Schulman, R. (2018). 2018 AAHA Diabetes Management Guidelines for Dogs and Cats. Journal of the American Animal Hospital Association. 54(1), 1-21. DOI: https://doi.org/10.5326/JAAHA-MS-6822

3. OCEBM. (2011). The Oxford 2011 Levels of Evidence. Available at: http://www.cebm.net/index.aspx?o=5653 [Accessed 10 August 2014].

4. Gilor, C, Rudinsky, A. J. \& Hall, M. J. (2016). New Approaches to Feline Diabetes Mellitus: Glucagon-like peptide-1 analogs. Journal of Feline Medicine and Surgery. 18(9), 733-743.

DOI: https://doi.org/10.1177\%2F1098612X16660441

5. Gostelow, R., Forcada, Y., Graves, T., Church, D. \& Niessen, S. (2014). Systematic review of feline diabetic remission: Separating fact from opinion. Veterinary Journal. 202(2), 208-221.

DOI: https://doi.org/10.1016/j.tvjl.2014.08.014

6. Gostelow, R., Scudder, C., Hazuchova, K., Forcada, Y., Church D. \& Niessen, S. (2017). 2017 ACVIM Forum Research Abstract Program Index of Abstracts ORAL PRESENTATIONS - Thursday, June 8. 1273.

7. Marshall, R. D., Rand, J. S. \& Morton, J. M. (2009). Treatment of Newly Diagnosed Diabetic Cats with Glargine Insulin Improves Glycaemic Control and Results in Higher Probability of Remission than Protamine Zinc and Lente Insulins. Journal of Feline Medicine and Surgery. 11(8), 683-691. DOI: https://doi.org/10.1016/j.jfms.2009.05.016

8. Nack, R. \& DeClue, A. E. (2014). In cats with newly diagnosed diabetes mellitus, use of a neareuglycemic management paradigm improves remission rate over a traditional paradigm. Veterinary Quarterly. 34(3), 132-136. DOI: https://doi.org/10.1080/01652176.2014.924057

9. Nelson, R. W., Henley, K., Cole, C. \& PZIR Clinical Study Group. (2009). Field safety and efficacy of protamine zinc recombinant human insulin for treatment of diabetes mellitus in cats. Journal of Veterinary Internal Medicine. 23(4), 787-793. DOI: https://doi.org/10.1111/i.1939-1676.2009.0342.x

10. Saini, N. K., Wasik, B., Pires, J., Leale, D. M., Quach, N., Culp, W. T. N., Samms, R. J., Johnson, A. E., Owens, J. G. \& Gilor, C. (2020). Comparison of pharmacodynamics between insulin glargine $100 \mathrm{U} / \mathrm{mL}$ and insulin glargine $300 \mathrm{U} / \mathrm{mL}$ in healthy cats. Domestic Animal Endocrinology. 75.

DOI: https://doi.org/10.1016/i.domaniend.2020.106595

11. Sparkes, A. H., Cannon, M., Church, D., Fleeman, L., Harvey, A., Hoenig, M., Peterson, M. E., Reusch, C. E., Taylor, S. \& Rosenberg, D. (2015). ISFM Consensus Guidelines on the Practical Management of Diabetes Mellitus in Cats. Journal of Feline Medicine and Surgery. 17(3), 235-250.

DOI: https://doi.org/10.1177\%2F1098612X15571880 


\section{EVIIDEFeE

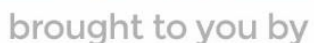 \\ RCVS KNOWLEDGE}

\section{Intellectual Property Rights}

Authors of Knowledge Summaries submitted to RCVS Knowledge for publication will retain copyright in their work, and will be required to grant RCVS Knowledge a non-exclusive license of the rights of copyright in the materials including but not limited to the right to publish, re-

publish, transmit, sell, distribute and otherwise use the materials in all languages and all media throughout the world, and to license or permit others to do so.

\section{Disclaimer}

Knowledge Summaries are a peer-reviewed article type which aims to answer a clinical question based on the best available current evidence. It does not override the responsibility

of the practitioner. Informed decisions should be made by considering such factors as individual clinical expertise and judgement along with patient's circumstances and owners' values. Knowledge Summaries are a resource to help inform and any opinions expressed within the Knowledge Summaries are the author's own and do not necessarily reflect the view of the RCVS Knowledge. Authors are responsible for the accuracy of the content. While the

Editor and Publisher believe that all content herein are in accord with current recommendations and practice at the time of publication, they accept no legal responsibility

for any errors or omissions, and make no warranty, express or implied, with respect to material contained within.

For further information please refer to our Terms of Use.

RCVS Knowledge is the independent charity associated with the Royal College of Veterinary Surgeons (RCVS). Our ambition is to become a global intermediary for evidence based veterinary knowledge by providing access to information

that is of immediate value to practicing veterinary professionals and directly contributes to evidence based clinical decision-making.

\section{https://www.veterinaryevidence.org/}

RCVS Knowledge is a registered Charity No. 230886.

Registered as a Company limited by guarantee in England and Wales No. 598443.

Registered Office: Belgravia House, 62-64 Horseferry Road, London SW1P 2AF

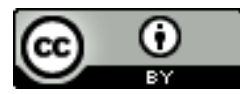

This work is licensed under a Creative Commons Attribution 4.0 International License. 